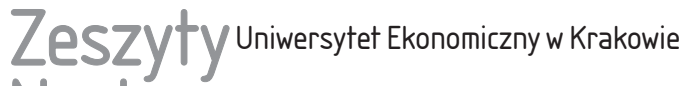 Naukowe
}

\section{Analiza rynku nieruchomości jako element diagnozy sfery gospodarczej w programach rewitalizacji w Polsce}

\section{Streszczenie}

Rynek nieruchomości rzadko jest analizowany w diagnozach sporządzanych na potrzeby opracowania programów rewitalizacji, mimo że niskie ceny nieruchomości i ich ograniczona płynność to jedne z głównych objawów niskiej atrakcyjności zdegradowanego obszaru. Potencjalny wzrost wartości nieruchomości może być też jednym z podstawowych powodów włączenia się w działania rewitalizacyjne przez właścicieli nieruchomości.

Celem artykułu jest przedstawienie potencjału analizy rynku nieruchomości w kontekście badania sfery gospodarczej na potrzeby wyznaczenia obszarów zdegradowanych w programach rewitalizacji.

Słowa kluczowe: rynek nieruchomości, rewitalizacja, diagnoza, sfera gospodarcza.

Klasyfikacja JEL: H76, R38, R58.

\section{Wprowadzenie}

Wraz z wejściem w życie Ustawy z dnia 9 października 2015 r. o rewitalizacji wprowadzono w Polsce ścisłe wymogi dotyczące wielkości obszarów

Aleksandra Jadach-Sepioło, Szkoła Główna Handlowa w Warszawie, Kolegium Nauk o Przedsiębiorstwie, Katedra Miasta Innowacyjnego, al. Niepodległości 162, 02-554 Warszawa, e-mail: a.jadachsepiolo@gmail.com 
rewitalizacji oraz liczby ich mieszkańców. Wyznaczanie obszarów, na których mają koncentrować się interwencje rewitalizacyjne (wspierane m.in. ze środków unijnych, ale i krajowych - publicznych i niepublicznych), odbywa się na podstawie wyników analizy skali degradacji w sferze społecznej, gospodarczej, technicznej, przestrzenno-funkcjonalnej i środowiskowej (art. 9 ust. 1 ustawy). Przeprowadzona diagnoza ma pozwolić na identyfikację najważniejszych skupisk zróżnicowanych problemów w gminie. Obszary te najczęściej charakteryzują się najniższą atrakcyjnością inwestycyjną, słabą kondycją przedsiębiorstw, najwyższym długotrwałym bezrobociem i najwyższym odsetkiem bezrobotnych o niskim poziomie wykształcenia i kwalifikacjach. Ponieważ w każdej gminie występuje specyficzne złożenie różnorodnych barier rozwoju przedsiębiorczości i postaw przedsiębiorczych, interwencja powinna być dopasowana do lokalnych uwarunkowań. Ich rozpoznanie w formie pogłębionej diagnozy to połowa sukcesu rewitalizacji.

W diagnozach sporządzanych na potrzeby opracowania programów rewitalizacji rynek nieruchomości rzadko jest przedmiotem odrębnej analizy, chociaż jego stan jest jednym z głównych objawów niskiej atrakcyjności zdegradowanego obszaru. Wzrost cen nieruchomości i liczby transakcji jest też często jedną z przyczyn włączenia się właścicieli nieruchomości w działania rewitalizacyjne.

Celem artykułu jest przedstawienie potencjału analizy rynku nieruchomości w kontekście badania sfery gospodarczej na potrzeby wyznaczenia obszarów zdegradowanych w programach rewitalizacji. Zazwyczaj analiza ta dokonywana jest przy spełnieniu minimalnych wymogów wynikających z ustawy o rewitalizacji, których rynek nieruchomości nie obejmuje. W artykule skonfrontowano więc zawartość diagnoz dotyczących sfery gospodarczej z zakresem informacji dotyczącym rynku nieruchomości, które mogą być cennym kontekstem dla planowanych działań rewitalizacyjnych. Badania przeprowadzono z wykorzystaniem bazy 656 programów rewitalizacji aktualnych w latach 2007-2013 (były to wszystkie programy rewitalizacji w Polsce w badanym okresie), analizując treść wszystkich dokumentów w trzech segmentach: diagnoza dotycząca sfery gospodarczej (wraz z odniesieniami do tej sfery w podsumowaniach diagnoz), cele i kierunki działania, projekty i instrumenty stymulujące rewitalizację na poziomie lokalnym wskazane w programie rewitalizacji.

W artykule przeprowadzono analizę polskiej literatury przedmiotu, wskazując na szerokie ujęcie problematyki rynku nieruchomości w kontekście działań rewitalizacyjnych z uwzględnieniem ich programowania. Następnie omówiono, w jaki sposób w programach rewitalizacji powstałych do końca 2015 r. ujmowano problematykę rynku nieruchomości. Na tej podstawie rekomendowano zespołom autorskim opracowującym obecnie programy rewitalizacji, w jaki sposób za pomocą 
analizy rynku nieruchomości można wzmocnić diagnozę. Ponieważ w większości gmin w Polsce kończą się lub jeszcze trwają prace nad opracowaniem programu rewitalizacji, artykuł ma istotne znaczenie praktyczne.

\section{Przegląd literatury}

W polskiej literaturze przedmiotu rynek nieruchomości stawał się przedmiotem analizy w zakresie rewitalizacji równolegle z rozwojem działań rewitalizacyjnych, które wiązały się ściśle z trudnymi warunkami mieszkaniowymi na zdegradowanych terenach (Bryx 1999, Gorgoń 2007). Stopniowo zakres analiz poszerzał się, przy czym najpełniejsze systemowe ujęcie infrastruktury tego rynku przedstawił M. Bryx (2009). Pogłębienia tej analizy ze wskazaniem relacji między rynkiem nieruchomości a procesami rewitalizacji miast dokonał M. Bryx (2013, s. 33-34) poprzez system zależności obejmujących następujące podsystemy tego rynku:

- obrotu,

- finansowania,

- inwestowania,

- zarządzania.

Każdy z wymienionych podsystemów powinien zostać odpowiednio dostosowany, aby mógł wspierać procesy rewitalizacji. M. Bryx dokonał ich oceny w polskich warunkach i przedstawił rekomendacje dotyczące usprawnien, wzorowane m.in. na zapisach niemieckiego kodeksu budowlanego. Instytucjonalne ujęcie rynku jest cenną wskazówką również w przypadku analizy funkcjonowania jego poszczególnych podsystemów na poziomie lokalnym.

Postawy podmiotów strony popytowej i podażowej rynku nieruchomości na obszarach zdegradowanych trafnie scharakteryzowała D. Kamrowska-Załuska (2014, s. 80-81), wykazując podstawową sprzeczność między długoterminową orientacją strony popytowej i krótkoterminową orientacją strony podażowej. To właśnie ta zależność tworzy istotną nierównowagę na lokalnym rynku nieruchomości i powoduje uruchomienie mechanizmu filtracji.

Najbardziej kompleksowe ujęcie mechanizmów występujących na rynku nieruchomości mieszkaniowych w kontekście rewitalizacji zaprezentował w polskiej literaturze przedmiotu A. Polko. Wyjaśnił on mikroekonomiczne mechanizmy degradacji tego rynku w obszarach kryzysowych - segregację dochodową, mechanizm filtracji i ,głosowanie nogami” Tiebouta - prowadzące ostatecznie do spadku wartości nieruchomości na obszarze zdegradowanym, któremu tylko świadomie prowadzona rewitalizacja może przeciwdziałać (Polko 2005).

Z innej perspektywy rynek nieruchomości analizował S. Belniak (2009), pokazując uwarunkowania prawne i techniczne działań inwestycyjnych na rynku 
nieruchomości w obszarach zdegradowanych. W szczególności analizie poddany został problem zużycia majątku trwałego i jego konsekwencje dla planowania działań remontowych. Stanowi to ważny przyczynek do analiz rewaloryzacyjnych oraz wskazówkę przy tworzeniu standardów wyceny budynków i lokali mieszkalnych na obszarach rewitalizacji (Belniak 2009, s. 111-118). Problematykę wyceny nieruchomości, szczególnie zabytkowych, w kontekście wzrostu wartości nieruchomości w obszarach rewitalizowanych podejmowała także autorka niniejszego artykułu, przedstawiając, w jaki sposób lokalizacja nieruchomości wpływa na jej potencjał zmiany wartości (Jadach-Sepioło 2009).

Analiza rynku nieruchomości, a zwłaszcza jego nasycenie i potrzeby zwiększenia dostępności lokali mieszkalnych, stanowi także istotną kwestię w przypadku działań planistycznych (Karadimitriou, de Magalhães i Verhage 2017, s. 14-17).

Zagadnienie rynku mieszkaniowego jako przedmiotu odrębnego wsparcia przedstawił na przykładzie miast śląskich S. Słupik (2008), wskazując na problem niskiej jakości zasobów mieszkaniowych oraz niewykorzystania potencjału wynikającego z niezagospodarowanych zasobów na rynku najmu.

\section{Analiza rynku nieruchomości w diagnozie sfery gospodarczej w programach rewitalizacji w latach 2007-2013}

Kryteria dotyczące wyznaczania obszarów zdegradowanych w perspektywie 2007-2013 zostały określone w art. 47 ust. 1 rozporządzenia Komisji (WE) nr 1828/2006:

„a) wysoki poziom ubóstwa i wykluczenia,

b) wysoka stopa długotrwałego bezrobocia,

c) niekorzystne trendy demograficzne,

d) niski poziom wykształcenia, wyraźny deficyt kwalifikacji i wysoki wskaźnik przerywania skolaryzacji,

e) wysoki poziom przestępczości i wykroczeń,

f) szczególnie wysoki stopień degradacji środowiska,

g) niski wskaźnik prowadzenia działalności gospodarczej,

h) wysoka liczba imigrantów, grup etnicznych i mniejszościowych lub uchodźców,

i) porównywalnie niski poziom wartości zasobu mieszkaniowego,

j) niski poziom wydajności energetycznej budynków".

Obszar, gdzie mogły być współfinansowane działania w zakresie mieszkalnictwa, musiał spełniać co najmniej trzy z wymienionych kryteriów, w tym przynajmniej spośród sygnowanych literami a-h. W kompetencjach poszczególnych 
państw członkowskich było określenie wartości referencyjnych dla wybranych wskaźników, przy czym wybór miał być przedmiotem uzgodnień z Komisją Europejską. W Polsce zakres kryteriów został w Wytycznych Ministra Rozwoju Regionalnego w zakresie programowania działań dotyczacych mieszkalnictwa (2008, s. 7) ograniczony do pięciu: a, b, e, g oraz i. Określono dla nich wskaźniki referencyjne na poziomie regionalnym. Poszczególne regiony stosowały zróżnicowane podejście do wyznaczania obszarów zdegradowanych, różnie też określały ich typy. W odniesieniu do obszarów zdegradowanych, na których miały być prowadzone działania z zakresu rewitalizacji obszarów miejskich, instytucje zarządzające regionalnymi programami operacyjnymi (IZ RPO) dopuszczały zastosowanie większej liczby kryteriów, najczęściej odwołując się wprost do pełnego katalogu wymienionego w art. 47 rozporządzenia Komisji (WE) nr 1828/2006. Zasadą było spełnienie co najmniej trzech dowolnych kryteriów spośród wymienionych.

W polskiej literaturze przedmiotu z tego okresu kryteria te są wprost przywoływane. Przykładem może być zestawienie S. Kozłowskiego i A. Wojnarowskiej, bazujące na ww. wytycznych ministerialnych. W badaniu zjawisk kryzysowych w sferze ekonomicznej i społecznej autorzy rekomendują uwzględnić następujące elementy (Kozłowski i Wojnarowska 2011, s. 21):

- gospodarkę i rynek pracy,

- poziom i strukturę wykształcenia,

- szanse zawodowe i społeczne,

- stopień aktywności i gotowości społeczności miejscowej do działań partycypacyjnych,

- stopień identyfikacji społeczności lokalnej z obszarem kryzysowym.

Odniesienie do wymogów unijnych spowodowało ograniczenie zagadnień rekomendowanych do analizy do podstawowych - wynikających z art. 47 ust. 1 rozporządzenia Komisji (WE) nr 1828/2006. Gospodarka w tym zestawieniu jest zdecydowanie obszerną kategorią, której jednak autorzy nie dookreślają.

Wśród kryteriów wyznaczania obszarów zdegradowanych określonych w art. 47 ust. 1 rozporządzenia Komisji (WE) nr 1828/2006 tylko jedno dotyczyło sfery gospodarczej, mianowicie niski wskaźnik prowadzenia działalności gospodarczej (litera g). Wytyczne Ministra Rozwoju Regionalnego w zakresie programowania działań dotyczacych mieszkalnictwa przyporządkowały do tego kryterium wskaźnik ,liczba zarejestrowanych podmiotów gospodarki narodowej na 100 osób" z wartością referencyjną na poziomie krajowym 8,6. Wskaźnik ten został zastosowany w każdej z metodyk regionalnych. Wymogi zawarte w wytycznych, zwłaszcza w sferze społecznej, były określane przez praktyków jako trudne do spełnienia ze względu na niską dostępność danych. Na tym tle stosunkowo łatwo można było pozyskać dane do wyznaczenia ww. wskaźnika gospodarczego. Jego 
zastosowanie było traktowane jako wystarczające do sformułowania określenia degradacji w sferze gospodarczej. Diagnoza tej sfery, którą zawierano w programach rewitalizacji, obejmowała - wprost za tym kryterium - kondycję lokalnych przedsiębiorstw i, na drugim miejscu, analizę rynku pracy, tj. największych pracodawców i główne branże w gminie. $Z$ tego powodu podstawowa informacja na temat rynku nieruchomości, którą można znaleźć w prawie każdym programie rewitalizacji z analizowanego okresu, to liczba przedsiębiorstw zajmujących się zgodnie z kodem PKD obsługą rynku nieruchomości (562 programy). Drugą z najczęściej powtarzających się informacji jest struktura własności nieruchomości w gminach. Na ogół podawane są zbiorcze dane, np. wykresy kołowe lub zestawienia tabelaryczne, przedstawiające procentowy udział poszczególnych typów własności. Nie znaleziono natomiast istotnych z punktu widzenia planowanych działań informacji o:

- szczegółowej strukturze własności i użytkowania terenów w obszarze rewitalizacji;

- nieruchomościach porzuconych lub o nieustalonym stanie prawnym, które $\mathrm{z}$ tego powodu niszczeją lub zostaje ustanowiony kurator ze względu na konieczność przeprowadzenia nagłych prac zabezpieczających z obciążeniem nieruchomości hipoteką na pokrycie kosztów;

- nieruchomościach w zasobach publicznych, planowanych do zbycia w obszarze rewitalizacji - pojawiają się sygnalne informacje o tym, że gmina posiada ofertę inwestycyjną, najczęściej w odniesieniu do obszarów poprzemysłowych, ale poza ogólnymi charakterystykami brakuje szczegółowych informacji. Jako przykład dobrej informacji można wymienić natomiast program rewitalizacji w Gubinie, w ramach którego podano zarówno charakterystykę stanu prawnego terenu, jak i planowane zagospodarowanie oraz plany zbywania kolejnych nieruchomości. Powszechne są natomiast krótkie informacje o potencjale inwestycyjnym, ograniczonym niską atrakcyjnością terenu: „na obszarze są działki do zagospodarowania, ale brakuje inwestora" (Strzelce Krajeńskie), lub informacje o braku możliwości podejmowania inwestycji przez właścicieli: „podstawowym problemem jest olbrzymia luka remontowa wiążąca się z niewydolnością finansową właścicieli nieruchomości” (Toruń).

Zdarzają się jednak programy, w których analizowane są cechy lokalnego rynku nieruchomości - wartość nieruchomości lub stawki czynszu w lokalach użytkowych. Najczęściej informacje te można znaleźć w podsumowaniach diagnoz, np. w tabelach przedstawiających wyniki analizy SWOT lub w zestawieniu występujących problemów na obszarze rewitalizacji. Są to stwierdzenia niepoparte w treści diagnozy szczegółową analizą danych, bazujące na obiegowych opiniach i przekonaniu sporządzających program. 
Tabela 1. Częstotliwość wykorzystania informacji o rynku nieruchomości w programach rewitalizacji

\begin{tabular}{|l|c|}
\hline \multicolumn{1}{|c|}{ Wyszczególnienie } & $\begin{array}{c}\text { Liczba } \\
\text { programów }\end{array}$ \\
\hline $\begin{array}{l}\text { Programy, w których zawarto informację o liczbie podmiotów gospodarczych } \\
\text { zajmujących się obsługą rynku nieruchomości w gminie }\end{array}$ & 562 \\
\hline $\begin{array}{l}\text { Programy, w których zawarto informację o strukturze własności terenów } \\
\text { w gminie }\end{array}$ & 321 \\
\hline $\begin{array}{l}\text { Programy, w których zawarto informację o potencjale obszaru rewitalizacji wyni- } \\
\text { kającym z lokalizacji wielu obiektów zabytkowych }\end{array}$ & 183 \\
\hline $\begin{array}{l}\text { Programy, w których zawarto informację o niskiej wartości nieruchomości na } \\
\text { wyznaczonym obszarze rewitalizacji w podsumowaniu diagnozy/analizie SWOT }\end{array}$ & 167 \\
\hline $\begin{array}{l}\text { Programy, w których zawarto informację o ofercie inwestycyjnej miasta na obsza- } \\
\text { rze rewitalizacji }\end{array}$ & 54 \\
\hline $\begin{array}{l}\text { Programy, w których zawarto informację o szansie na odnowę miasta, wynikają- } \\
\text { cej z niższych cen nieruchomości w porównaniu z najbliższym dużym miastem }\end{array}$ & 24 \\
\hline $\begin{array}{l}\text { Programy, w których jako cel sformułowano przywrócenie nieruchomościom ich } \\
\text { utraconej wartości lub podobny }\end{array}$ & 75 \\
\hline $\begin{array}{l}\text { Programy, w których wskazano instrumenty lokalne wspierające odnowę na rynku } \\
\text { nieruchomości, np. zwolnienia z podatku od nieruchomości dla właścicieli podej- } \\
\text { mujących remonty lub porządkujących przyległy teren, pożyczki }\end{array}$ & 12 \\
\hline
\end{tabular}

Źródło: opracowanie własne.

Skąpym informacjom w częściach diagnostycznych odpowiada także słabe odniesienie do problematyki rynku nieruchomości w celach programów oraz w stosowanym przez gminy instrumentarium. Cel związany z rewaloryzacją nieruchomości na obszarze rewitalizacji sformułowało 75 gmin spośród analizowanych. Należy jednak zwrócić uwagę na to, że istotne znaczenie ma w tym przypadku semantyka - najpowszechniejszym celem określonym w programach rewitalizacji jest odnowa zasobów nieruchomościowych wskazana we wszystkich dokumentach. Trudno jednak odnowę fizyczną utożsamiać z celem ekonomicznym związanym nie tylko z poprawą standardu, ale przede wszystkim ze zwiększeniem płynności na lokalnym rynku nieruchomości i wzrostem cen transakcyjnych. Jedynie dla 75 gmin (11,43\% badanych) jednym z głównych celów rewitalizacji była właśnie ta zmiana na rynku nieruchomości.

Jeszcze mniej gmin realizuje ten cel poprzez zastosowanie specjalnie dobranego instrumentarium, np. fiskalnego lub pożyczkowego. Dominuje przekonanie, że wystarczą działania remontowe, aby sytuacja poprawiła się, a konieczne wsparcie powinno ograniczać się do dotacji unijnych dla właścicieli budynków. Tym bardziej na uwagę zasługują instrumenty stosowane w nielicznych gminach, 
takie jak pożyczki z budżetu miasta dla właścicieli kamienic na remonty (Bydgoszcz, Stargard) czy zwolnienia z podatku od nieruchomości (np. Bełchatów, Kalisz, Rybnik, Sosnowiec, Toruń, Wodzisław Śląski). Instrumenty fiskalne zaczynają być stosowane często w połączeniu ze stymulowaniem tworzenia miejsc pracy, warto więc upowszechnić je także w powiązaniu z rewitalizacją. Przykładem innowacji w tym zakresie może być wprowadzone uchwałą Rady Miasta Bełchatowa zwolnienie od podatku od nieruchomości dla właścicieli, którzy podjęli starania dotyczące porządkowania swoich podwórzy poprzez likwidację starej zabudowy gospodarczej (komórki, garaże) czy roboty brukarskie oraz otworzyli i udostępnili podwórza dla innych mieszkańców.

\section{Kondycja rynku nieruchomości jako odzwierciedlenie negatywnych zjawisk w obszarze rewitalizacji - rekomendacje dotyczące programów rewitalizacji po 2015 roku}

Analiza programów rewitalizacji uchwalonych przez gminy w Polsce do połowy 2016 r. wykazała, że w diagnozie kryzysu sfery gospodarczej oraz delimitacji obszarów zdegradowanych i obszarów rewitalizacji stosowano najczęściej następujące wskaźniki (Jadach-Sepioło i Krystek-Kucewicz 2016):

- liczba zarejestrowanych podmiotów gospodarki narodowej na 100 osób,

- odsetek osób w wieku poprodukcyjnym w ogólnej liczbie mieszkańców,

- odsetek osób bezrobotnych z wykształceniem gimnazjalnym i niższym w ogólnej liczbie bezrobotnych.

Podobnie jak w poprzednim okresie programowania rynek nieruchomości nie jest szczegółowo badany w diagnozach dotyczących obszaru rewitalizacji. W literaturze przedmiotu pojawiają się jednak sygnały, że ta problematyka może wzbogacić wnioskowanie na temat czynników negatywnych na tych obszarach i ich potencjałów.

J. Przywojska, analizując diagnozowanie negatywnych zjawisk w sferze społecznej na potrzeby opracowania programów rewitalizacji, przedstawiła różnorodne metody ilościowe, ale i jakościowe, w szczególności - obserwacyjne metody pomiaru lokalnej gospodarki. Jedną z kwestii polecanych do badania in situ jest miks usług obszaru kryzysowego (lombardy, „chwilówki”, „wszystko po 5 zł”, hazard). „Każda z tych usług może lokować się także poza obszarem rewitalizacji, jednak fakt ich koncentracji w jakiejś części miasta oznacza, że rynek »wyczuł« skumulowane tam ubóstwo i obecność klientów zmuszonych do zastawiania i sprzedawania przedmiotów, do szukania szans w zakładach bukmacherskich i kupowania towarów za minimalne ceny, bez względu na ich jakość" (Przywojska 2016, s. 159). Autorka wskazała także na inny problem lokalnego rynku nieru- 
chomości - nierównowagę między popytem na lokale użytkowe a podażą. Jeśli w obszarze zdegradowanym dochody z usług są ograniczone w związku z niską siłą nabywczą mieszkańców, nie ma sensu lokowanie tam działalności handlowych i usługowych. Podaż lokali pozostaje niezrównoważona popytem, przez co w pierzejach ulic, a jeszcze bardziej w oficynach i podwórkach widoczne są pustostany, często zdekapitalizowane z powodu długiego okresu nieużytkowania. Prowadzone działalności natomiast przy niskiej lub bardzo niskiej rentowności nie pozwalają na podejmowanie nawet minimalnych remontów.

Analizy rynku nieruchomości to także niezbędny element badań przestrzennego wymiaru społecznych zróżnicowań w mieście. M. Szmytkowska (2008) podkreślała konieczność obserwacji zmian renty gruntowej jako miernika zmian społecznych i przedstawiła analizę zmian ceny działek w zależności od lokalizacji w Gdyni, zestawiając jej wynik z peryferyjnym rozmieszczeniem enklaw biedy w Gdyni (Szmytkowska 2008, s. 164-175). Analizy zmian renty gruntowej są zbyt dużym wyzwaniem badawczym na potrzeby programów rewitalizacji, warto więc wskazać elementy, których uwzględnienie może wspomóc pogłębioną diagnozę dotyczącą obszaru rewitalizacji w sferze gospodarczej:

- liczba transakcji na lokalnym rynku nieruchomości,

- ceny ofertowe i transakcyjne na rynku nieruchomości,

- ceny najmu lokali użytkowych.

Dane te powinny być analizowane zawsze na poziomie całego miasta oraz dla obszaru rewitalizacji i innych obszarów w mieście, dzięki czemu możliwe jest porównanie płynności, dynamiki i wolumenu rynku nieruchomości w skali wewnątrzmiejskiej. Wartościowych informacji dostarczają także przywołane informacje o strukturze działalności gospodarczych w obszarze rewitalizacji, np. o liczbie banków, lombardów czy sklepów z używaną odzieżą. Zakres wykorzystanych informacji zależy od charakterystyki obszaru i trudno podać gotowy sposób na pełną diagnozę dotyczącą rynku nieruchomości w sferze gospodarczej. W przypadku obszaru o dużej liczbie obiektów zabytkowych ważną kwestią będzie poziom środków na dotacje konserwatorskie w tym obszarze w relacji do całego miasta, dla obszaru poprzemysłowego z kolei - informacje o uzbrojeniu, potencjalnych zanieczyszczeniach i sąsiadujących zakładach przemysłowych.

\section{Podsumowanie}

W artykule omówiono, jakiego rodzaju dane dominują w diagnozie zjawisk negatywnych w programach rewitalizacji, wykazując marginalny charakter kluczowych informacji dotyczących rynku nieruchomości. Na podstawie literatury przedmiotu wskazano jednocześnie, w jakim zakresie analiza rynku nierucho- 
mości może wspierać diagnozę problemów w sferze gospodarczej na potrzeby wyznaczenia obszarów zdegradowanych w programach rewitalizacji. Badania przeprowadzono na podstawie bazy 656 programów rewitalizacji, dzięki czemu uzyskano pełny obraz informacji o rynku nieruchomości, które są dostępne w programach rewitalizacji w całej Polsce. Na tej podstawie jednoznacznie stwierdzono, że rynek nieruchomości w bardzo ograniczonym zakresie jest analizowany w programach rewitalizacji, mimo że w dokumentach tych pojawiają się niepoparte danymi informacje o niskiej wartości nieruchomości, małej liczbie transakcji nieruchomościowych na obszarze rewitalizacji czy słabej ofercie inwestycyjnej. Rozdźwięk między brakiem danych a obiegowymi opiniami może być znaczny. Z tego względu w części poświęconej rekomendacjom dla tworzących obecnie programy rewitalizacji wskazano, jakie dane mogą pozwolić na weryfikację obiegowych opinii i pozwolić na lepsze dopasowanie stosowanych narzędzi do faktycznie występujących problemów. Problem rewaloryzacji ekonomicznej nieruchomości na obszarze rewitalizacji ma przecież fundamentalne znaczenie dla zwiększenia zdolności właścicieli nieruchomości do prowadzenia działań inwestycyjnych. Warto wspomnieć choćby zwiększenie wartości potencjalnych kredytów, których zabezpieczeniem mogą być te nieruchomości.

\section{Literatura}

Belniak S. (2009), Rewitalizacja nieruchomości w procesie odnowy miast, Wydawnictwo Uniwersytetu Ekonomicznego w Krakowie, Kraków.

Bryx M. (1999), Finansowanie rozwoju budownictwa mieszkaniowego w miastach, Monografie i Opracowania, nr 452, Oficyna Wydawnicza Szkoły Głównej Handlowej, Warszawa.

Bryx M. (2009), Infrastruktura rynku nieruchomości jako wsparcie procesów rewitalizacji - luka instytucjonalna i regulacyjna (w:) Finansowanie i gospodarka nieruchomościami w procesach rewitalizacji, red. M. Bryx, Rewitalizacja Miast Polskich, nr 7, Instytut Rozwoju Miast, Kraków.

Bryx M. (2013), Rynek nieruchomości a procesy rewitalizacji miast (w:) Rynek nieruchomości. Finansowanie rozwoju miast, red. M. Bryx, CeDeWu, Warszawa.

Gorgoń J. (2007), Znaczenie przekształceń terenów miejsko-przemysłowych w procesie rewitalizacji miast (w:) Rewitalizacja miast w Polsce. Pierwsze doświadczenia, red. P. Lorens, Biblioteka Urbanisty, nr 10, Urbanista, Warszawa.

Jadach-Sepioło A. (2009), Możliwości zarzadzania wartościa nieruchomości w rewitalizacji polskich miast (w:) Aspekty prawne i organizacyjne zarzadzania rewitalizacja, red. W. Rydzik, Rewitalizacja Miast Polskich, nr 6, Instytut Rozwoju Miast, Kraków.

Jadach-Sepioło A., Krystek-Kucewicz B. (2016), Dobór wskaźników zjawisk kryzysowych - stan zaawansowania procesu delimitacji obszarów rewitalizacji w polskich miastach, „Problemy Rozwoju Miast”, nr 4.

Kamrowska-Załuska D. (2014), Zrównoważona odnowa przestrzeni miejskiej, „Studia KZPK PAN", vol. 158. 
Karadimitriou N., de Magalhães C., Verhage R. (2017), Planning, Risk and Property Development. Urban Regeneration in England, France and the Netherlands, Routledge, LondonNew York.

Kozłowski S., Wojnarowska A. (2011), Rewitalizacja zdegradowanych obszarów miejskich. Zagadnienia teoretyczne, Wydawnictwo Uniwersytetu Łódzkiego, Łódź.

Polko A. (2005), Miejski rynek mieszkaniowy i efekty sasiedztwa, Wydawnictwo Akademii Ekonomicznej w Katowicach, Katowice.

Przywojska J. (2016), Rewitalizacja miast. Aspekt społeczny, Akademia Samorządowa, Wydawnictwo Uniwersytetu Łódzkiego, Łódź.

Rozporządzenie Komisji (WE) nr 1828/2006 z dnia 8 grudnia 2006 r. ustanawiające szczegółowe zasady wykonania rozporządzenia Rady (WE) nr 1083/2006 ustanawiającego przepisy ogólne dotyczące Europejskiego Funduszu Rozwoju Regionalnego, Europejskiego Funduszu Społecznego oraz Funduszu Spójności oraz rozporządzenia (WE) nr 1080/2006 Parlamentu Europejskiego i Rady w sprawie Europejskiego Funduszu Rozwoju Regionalnego, Dz.Urz. UE, L 371 z 27.12.2006.

Słupik S. (2008), Realizacja społecznej polityki mieszkaniowej jako czynnik zapobiegajacy wykluczeniu społecznemu (w:) Rewitalizacja obszarów wykluczenia społecznego w miastach ślaskich, red. D. Kotlorz, Wydawnictwo Akademii Ekonomicznej w Katowicach, Katowice.

Szmytkowska M. (2008), Przestrzeń społeczna miasta w okresie transformacji. Przypadek Gdyni, Wydawnictwo Naukowe Scholar, Warszawa.

Ustawa z dnia 9 października 2015 r. o rewitalizacji, t.j. Dz.U. 2017, poz. 1023, 1529, 1566. Wytyczne Ministra Rozwoju Regionalnego w zakresie programowania działań dotyczacych mieszkalnictwa (2008), Minister Rozwoju Regionalnego, Warszawa.

\section{Analysis of the Real Estate Market in Assessment of the Economy in Urban Regeneration Programs in Poland}

(Abstract)

The real estate market is rarely analysed as a component of economic assessments during the preparation of urban regeneration programs, though low real estate prices and their limited liquidity are often main reasons for a degraded area's lack of attractiveness. The potential increase in the value of real estate may also be one of the basic motivators to engage in property revitalisation activities.

The article presents the potential of the real estate market analyses in the context of delimiting degraded areas in urban regeneration programs and the attendant study of the economy.

Keywords: real estate market, urban regeneration, diagnosis, economic sphere. 